\title{
INCLUSIVE TOURISM AS A SCIENTIFIC PROBLEM: AN INTERDISCIPLINARY APPROACH
}

\section{ІНКЛЮЗИВНИЙ ТУРИЗМ ЯК НАУКОВА ПРОБЛЕМА: МІЖДИСЦИПЛІНАРНИЙ ПІДХІД}

\section{Oksana Kravchenko ${ }^{1}$}

DOI: https://doi.org/10.30525/978-9934-588-53-2-18

Abstract. The article defines that an interdisciplinary approach is able to provide a comprehensive justification and development of the system of social and psychological rehabilitation of children and young people with special educational needs by means of inclusive tourism at the methodological, technological, practical and organizational levels. The purpose of the methodological level is to integrate laws and principles, to complement different concepts and methods of scientific knowledge of the essence and sources of origin, formation and approval of inclusion in education, to implement innovative practices and technologies of social and psychological rehabilitation. In the process of interdisciplinary synthesis some issues need to be considered. They include the issue of diffusion into the educational inclusion of concepts, models, principles, methods, ontological representations from other scientific fields (inclusion, tourism, social work, pedagogy, social pedagogy, psychology, local history, rehabilitation geography, medical rehabilitation, etc.), the appropriateness and validity of their application for the development of innovative theories and technologies of social and psychological rehabilitation.

Technological level of integration is a practical embodiment of concepts, theories, systems in the form of an interdisciplinary team, which includes educators, psychologists, social educators and social workers, physicians, rehabilitators, tourism instructors, country desk officers, and parents. The level of effectiveness of the interdisciplinary team activity in terms of social and psychological rehabilitation is determined by a set of methods, the main

\footnotetext{
${ }^{1}$ Doctor of Pedagogical Sciences, Professor, Dean of the Faculty of Social and Psychological Education, Pavlo Tychyna Uman State Pedagogical University, Ukraine 
of which are observation, situation analysis, analysis of results of activities, questioning, testing, independent characteristics method, method of expert evaluation, comparative analysis, classification, systematization, typology, scaling, modeling and more. In order to apply these methods, there are a number of features that must be taken into account in the process of social and psychological rehabilitation: the level of competence of specialists, their level of knowledge is of great importance for the accuracy of assessment; the possibility of tolerance of certain subjectivity in the assessment and conclusions. The analysis of the results obtained should be based not only on the formal result of the obtained estimates processing, but also on the interpretation of these results by experts. Therefore, qualitative indicators that reflect the opinion of an interdisciplinary team should be used to assess the individual development of children with special educational needs.

Organizational level envisages the development of a single purpose of work for various specialized institutions and establishments (Centers of medical and social expertise of the Ministry of Health of Ukraine; Department of Labor and Social Protection of the population of the Ministry of Social Policy of Ukraine; educational institutions of all levels, inclusive-resource centers, psychological service of the Ministry of Education and Science of Ukraine; public organizations of the disabled and their unions) regarding the provision of comprehensive rehabilitation assistance for people with disabilities.

Thus, a theoretical understanding of key issues of social and psychological rehabilitation of children and young people with special educational needs through inclusive tourism is possible only within the framework of a multidisciplinary approach that provides fundamental analysis, interpretation and integration of knowledge, the use of different cognition methods, which may lead to the new stage of its development, adequate to the modern dynamics of social relations.

\section{1. Вступ}

Довгий час існувала єдина модель надання допомоги людям з інвалідністю - медична, яка передбачала розв'язання їхніх соціальних проблем виключно шляхом медичного втручання. Така модель полягає в тому, що людина з інвалідністю розглядається як пацієнт, іiі труднощі співвідносяться лише з особливостями обмеження життєдіяльності. За такого підходу вона стає пасивною у процесі лікування і догляду. 
Соціальна модель виникла і сформувалася як виклик медичній, тому ії метою стала підтримка й активізація позитивного потенціалу людей з інвалідністю на шляху до максимальної самостійності та інтегрованості у соціум. Саме соціальна модель стала передумовою появи міждисциплінарного підходу у розв'язанні складної проблеми, яка довгий час існувала у суспільстві.

Суперечності між медичною і соціальною моделями у розумінні проблем людей з інвалідністю потребують особливої уваги при виробленні концепції міждисциплінарної допомоги, інтегрованої підтримки, ефективної співпраці медичних і соціальних працівників, педагогів, психологів та інших фахівців.

Аналіз останніх досліджень явища міждисциплінарності передбачає вичерпну і комплексну характеристику цього феномену. У цьому контексті заслуговують на увагу узагальнення О. Гордійчука, який розглядає міждисциплінарний підхід 3 кількох позицій: 1. Міждисциплінарність - це взаємопроникнення, взаємозбагачення підходів і методів різних наук (дисциплін). 2. Міждисциплінарність - це можливість виявити, розпізнати, сприйняти те, що було прихованим у надрах окремо взятої науки за умови використання методів та інструментарію інших наук. 3. Міждисциплінарність - це запозичення взаємопов'язаними науками методів, інструментарію, результатів дослідження, використання їхніх теоретичних схем, моделей, категорій, понять. 4. Міждисциплінарність - це не лише запозичення методів, інструментарію різних наук, а й інтеграція останніх у сенсі конструювання міждисциплінарних об'єктів, предметів, опрацювання яких дозволяє отримати нове наукове знання. 5. Міждисциплінарність - це науково-педагогічна новація, що породжує здатність побачити, розпізнати, сприйняти те, що є недоступним у межах окремо взятої науки з її специфічним, вузькоорієнтованим об' єктом, предметом і методами дослідження. 6. Міждисциплінарність - у широкому, функціональному іiі розумінні - це синергія різних наук, що передбачає розвиток інтеграційних процесів, взаємодію методів, інструментарію задля отримання нового наукового знання [4].

Зарубіжним ученим Е. Мирським виділено три види проблем, які можна розв'язати у процесі міждисциплінарних досліджень: методологічні (формування об'єкта дослідження в різних предметних проекціях); організаційні (створення мережі комунікації представників 
різних наукових дисциплін); інформаційні (передача прикладних результатів міждисциплінарного дослідження у практику прийняття рішень та їх технологічного втілення, а також передача власне наукових результатів для експертизи у системі дисциплінарного знання) [8].

Загалом важливою характеристикою міждисциплінарного дослідження є його орієнтування на проблему, що дозволяє виявити принципово нове знання на перетині окремих дисциплін. Водночас самі дисципліни після такого інтегрування не припиняють свого існування, а лише збагачуються новими принципами дослідження. Наразі існує безліч наукової інформації, і вона, як правило, диференційована на ізольовані частини, навіть у межах однієї дисципліни. 3 огляду на це, потрібен орієнтир для іiї синтезу чи інтеграції, який може надати лише міждисциплінарний підхід, що водночас засвідчує його актуальність. Очевидно, що міждисциплінарний підхід є одним із методологічних взірців адекватності, конструктивності і семантичної визначеності наукового пошуку і його результатів [15].

На практиці міждисциплінарний підхід може реалізовуватися за двома основними форматами (сценаріями, або підходами). За першого формату, найбільш поширеного, міждисциплінарність, образно кажучи, будує мости між різними науками, неформально об'єднує їх, не порушуючи їх індивідуальності, унікальності, своєрідності. За другого формату міждисциплінарність постає як реальний інструмент об'єднання наук, появи інтегрованих продуктів, проєктів, міждисциплінарних об’єктів дослідження [4].

У цьому контексті ставимо за мету розглянути систему соціально-психологічної реабілітації дітей та молоді з особливими освітніми потребами засобами інклюзивного реабілітаційно-соціального туризму як міждисциплінарний предмет дослідження, що передбачає синтез окремих наукових дисциплін: інклюзії, туризму, соціальної роботи, педагогіки, соціальної педагогіки, психології, краєзнавства, реабілітаційної географії, медичної реабілітації тощо. Утворення комплексу цих дисциплін, що фокусуються на предметі дослідження 3 позицій власної предметної проекції, дозволяє отримати цілісне знання про феномен інклюзивного реабілітаційно-соціального туризму.

Таке інтегрування знань, у процесі якого окремі дисципліни зберігають свою самостійність і специфічність, але їх теоретичні концепції і фак- 
тичні дані об’єднуються навколо методів дослідження проблем інклюзії та соціально-психологічної реабілітації дітей і молоді з особливими освітніми потребами, сприяє підвищенню їх практичної ефективності.

Евристичні ресурси міждисциплінарного підходу не тільки дозволяють здійснювати осмислення інклюзивних освітньо-виховних процесів в межах конкретної наукової дисципліни, а й розширюють дослідницький потенціал соціально-виховних процесів методологією й методами пізнання як гуманітарних, так і природничих наук. Міждисциплінарність у постановці проблем і підходах до їх розв'язання проявляється в аналізі інноваційних теорій різних наукових галузей, виявленні змістових, логічних, функціональних зв'язків між ними, синтезі поглядів на інноваційні процеси й формуванні нових теорій та концепцій інклюзії в освіті. У контексті інноваційних змін когнітивні практики тяжіють до міждисциплінарного синтезу, тому що міждисциплінарність пов'язана зі здатністю всебічно підходити до аналізу завдань і дозволяє вивчати те, що неможливо побачити, сприйняти в межах однісї наукової дисципліни з їі специфічними об’єктом, предметом і методами дослідження [7].

Застосування міждисциплінарного підходу в обгрунтуванні системи соціально-психологічної реабілітації пов'язане з потребою в синтезі й взаємозбагаченні наявних концепцій інклюзивного освітньо-виховного процесу. При цьому процес взаємопроникнення категорій, екстраполяції підходів проявляється як в узагальненні часткових, так і в конкретизації загальних підходів, проникненні їх з однієї наукової галузі в іншу. В результаті це сприяє створенню інтегративної системи знань про інклюзивні освітньо-виховні процеси з позицій пошуку інноваційних та ефективних засобів соціально-психологічної реабілітації дітей та молоді з інвалідністю. Така система цілісно й логічно відображає сукупність наукових уявлень про всі їх складові й фактори.

\section{2. Методологічний рівень міждисциплінарного дослідження}

Рівень міждисциплінарного дослідження соціально-психологічної реабілітації дітей та молоді з інвалідністю засобами інклюзивного туризму називаємо методологічним, адже він дозволяє виявити дослідницький потенціал декількох галузей наукового знання чи наукових дисциплін, а також визначити їхній внесок у теоретичне обгрунтування проблеми дослідження (табл. 1). 
Таблиця 1

Методологічний рівень міждисциплінарного дослідження соціально-психологічної реабілітації дітей та молоді
3 інвалідністю засобами інклюзивного туризму

\begin{tabular}{|c|c|c|}
\hline $\begin{array}{c}\text { Назва } \\
\text { наукової } \\
\text { дисципліни }\end{array}$ & Сфера наукового пізнання & $\begin{array}{c}\text { Дослідницький потенціал щодо } \\
\text { предмета дослідження }\end{array}$ \\
\hline 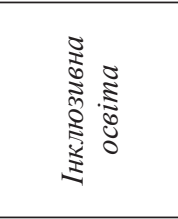 & $\begin{array}{l}\text { Передбачає створення освіт- } \\
\text { нього середовища, яке б } \\
\text { відповідало потребам і мож- } \\
\text { ливостям кожної дитини, } \\
\text { незалежно від особливостей } \\
\text { їі психофізичного розвитку }\end{array}$ & $\begin{array}{l}\text { Інноваційною послугою інклюзив- } \\
\text { ного закладу освіти є інклюзивний } \\
\text { реабілітаційно-соціальний туризм, } \\
\text { що потребує наукового обгрунту- } \\
\text { вання упровадження в інклюзив- } \\
\text { ному освітньому середовищі }\end{array}$ \\
\hline 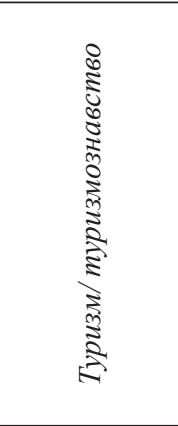 & $\begin{array}{l}\text { Має важливе значення в } \\
\text { житті людей, безпосеред- } \\
\text { ньо впливає на соціальну, } \\
\text { культурну, освітню, полі- } \\
\text { тичну, економічну сфери, } \\
\text { міжнародні зв’язки держав, } \\
\text { забезпечує мир і міжна- } \\
\text { родне взаєморозуміння, } \\
\text { відповідно розробляє теоре- } \\
\text { тико-методологічні основи } \\
\text { цілісної концепції туризму }\end{array}$ & $\begin{array}{l}\text { Саме туризмознавство дозволяє } \\
\text { з'ясувати функції туризму - культуро- } \\
\text { логічні, світоглядні, виховні, реабілі- } \\
\text { таційні, що й потребує подальшого } \\
\text { вивчення у межах предмета дослід- } \\
\text { ження. До того ж доцільно допов- } \\
\text { нити типологію туризму за ознаками } \\
\text { спрямованості на потреби туристичної } \\
\text { подорожі - інклюзивний реабіліта- } \\
\text { ційно-соціальний туризм - поряд із } \\
\text { спортивним, лікувальним, релігійним, } \\
\text { пізнавальним та ін. }\end{array}$ \\
\hline $\begin{array}{c}0 \\
0 \\
0 \\
0 \\
0 \\
0 \\
0 \\
0 \\
0 \\
0 \\
0 \\
0 \\
0 \\
0 \\
0\end{array}$ & $\begin{array}{l}\text { Досліджує вплив соціаль- } \\
\text { них явищ, процесів і відно- } \\
\text { син на соціальне функціо- } \\
\text { нування спільнот, груп чи } \\
\text { окремих індивідів }\end{array}$ & $\begin{array}{l}\text { У цьому відношенні потребують } \\
\text { наукового обгрунтування організаційні } \\
\text { та змістові засади надання соціаль- } \\
\text { ної послуги інклюзивного туризму, } \\
\text { а також висвітлення форм, методів і } \\
\text { підходів до проблеми надання профе- } \\
\text { сійної допомоги людям з інвалідністю } \\
\text { різних нозологій }\end{array}$ \\
\hline 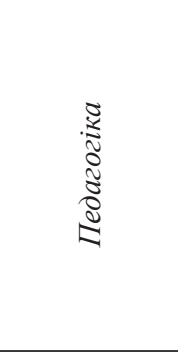 & $\begin{array}{l}\text { Предметом педагогіки } \\
\text { як науки про виховання, } \\
\text { навчання і освіту людини } \\
\text { є обгрунтування найбільш } \\
\text { ефективних шляхів соціа- } \\
\text { лізації молодих поколінь. } \\
\text { Предмет конкретизується } \\
\text { у завданнях: розробка і } \\
\text { впровадження теоретичних } \\
\text { основ процесу навчання і }\end{array}$ & $\begin{array}{l}\text { Актуалізується потреба у теоре- } \\
\text { тичній розробці та практичному } \\
\text { впровадженні інклюзивного туризму } \\
\text { як форми організації виховного } \\
\text { процесу }\end{array}$ \\
\hline
\end{tabular}


(Продовження таблиці 1)

\begin{tabular}{|c|c|c|}
\hline $\begin{array}{c}\text { Назва } \\
\text { наукової } \\
\text { дисципліни }\end{array}$ & Сфера наукового пізнання & $\begin{array}{c}\text { Дослідницький потенціал } \\
\text { щодо предмета дослідження }\end{array}$ \\
\hline & $\begin{array}{l}\text { виховання; визначення змі- } \\
\text { сту навчання і виховання; } \\
\text { розробка ефективних форм } \\
\text { і методів навчально-вихов- } \\
\text { ного процесу. }\end{array}$ & \\
\hline 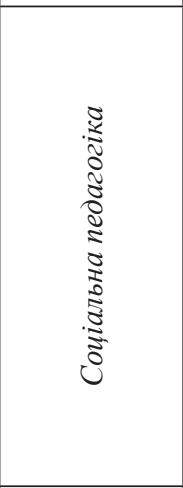 & $\begin{array}{l}\text { Вивчає процес соціалізації } \\
\text { особистості }\end{array}$ & $\begin{array}{l}\text { Дієвою формою інтеграції суспіль- } \\
\text { но-виховних зусиль, спрямованих на } \\
\text { соціалізацію особистості, може стати } \\
\text { інклюзивний туризм, який дозволяє } \\
\text { включити дитину з особливими освіт- } \\
\text { німи потребами у соціальні відносини, } \\
\text { створити умови, які допомагають їй } \\
\text { пізнати соціальну дійсність і засвоїти } \\
\text { позицію суб'єкта соціального життя. } \\
3 \text { цього виникає потреба у подальших } \\
\text { наукових студіях з обгрунтування } \\
\text { соціально-педагогічних умов успішної } \\
\text { соціалізації дітей та молоді з інвалідні- } \\
\text { стю засобами інклюзивного туризму }\end{array}$ \\
\hline 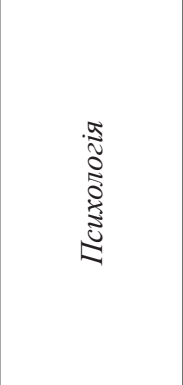 & $\begin{array}{l}\text { Галузь науки, яка дослі- } \\
\text { джує процеси виникнення, } \\
\text { функціонування й розвитку } \\
\text { психіки як форми активного } \\
\text { відображення навколишньої } \\
\text { дійсності }\end{array}$ & $\begin{array}{l}\text { У цьому відношенні актуалізуються } \\
\text { питання теоретичного обгрунтування } \\
\text { та практичного впровадження методик, } \\
\text { прийомів і технологій надання психо- } \\
\text { логічної допомоги дітям та молоді } 3 \\
\text { інвалідністю з урахуванням їхніх інди- } \\
\text { відуальних, вікових і соціальних осо- } \\
\text { бливостей, розуміння індивідуальності } \\
\text { кожного крізь призму специфічних } \\
\text { життєвих обставин, життєвого шляху, } \\
\text { проблем і життєвих перспектив }\end{array}$ \\
\hline 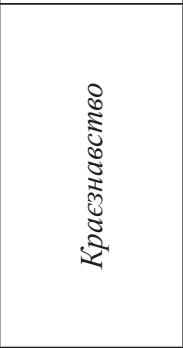 & & $\begin{array}{l}\text { У цьому відношенні заслуговує на } \\
\text { увагу наукове вивчення виховного } \\
\text { впливу шкільного краєзнавства на } \\
\text { вольову, емоційну й інтелектуальну } \\
\text { сфери дітей та молоді, у тому числі з } \\
\text { інвалідністю, а також обгрунтування } \\
\text { функцій, які краєзнавство виконує, } \\
\text { зокрема освітньо-пізнавальної, вихов- } \\
\text { но-розвивальної, соціалізаційної, куль- } \\
\text { турно-дозвіллєвої й оздоровчої }\end{array}$ \\
\hline
\end{tabular}


(Закінчення таблиці 1)

\begin{tabular}{|c|c|c|}
\hline $\begin{array}{c}\text { Назва } \\
\text { наукової } \\
\text { дисципліни }\end{array}$ & Сфера наукового пізнання & $\begin{array}{c}\text { Дослідницький потенціал } \\
\text { щодо предмета дослідження }\end{array}$ \\
\hline 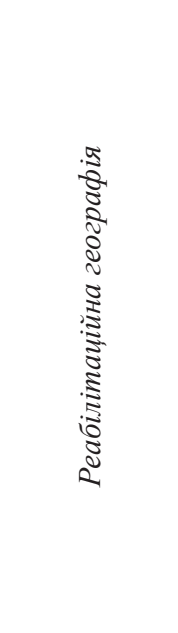 & $\begin{array}{l}\text { Напрям географічної науки, } \\
\text { який передбачає інтеграцію } \\
\text { основних реабілітаційних } \\
\text { складових природного } \\
\text { та антропотехногенного } \\
\text { характеру для відновлення } \\
\text { емоційного, фізичного, пси- } \\
\text { хологічного стану людини. } \\
\text { Потрібен комплексний під- } \\
\text { хід до розв’язання питань } \\
\text { інклюзивної реабілітації у } \\
\text { вигляді соціально-психоло- } \\
\text { гічної, медичної, фізіологіч- } \\
\text { ної (оздоровчо-лікувальної) } \\
\text { та рекреаційної допомоги } \\
\text { різними видами інклюзив- } \\
\text { ного реабілітаційно-соці- } \\
\text { ального туризму }\end{array}$ & $\begin{array}{l}\text { Перспективними напрямками } \\
\text { подальших наукових досліджень у } \\
\text { галузі географії є оцінка реальної } \\
\text { картини потенціального викори- } \\
\text { стання серед населення реабілітаці- } \\
\text { йних послуг з урахуванням наяв- } \\
\text { ного потенціалу, а також вивчення } \\
\text { закономірностей формування та } \\
\text { функціонування територіальних } \\
\text { рекреаційних систем, що склада- } \\
\text { ються з природних і культурних } \\
\text { комплексів, інженерних споруд, які } \\
\text { використовуються для рекреації }\end{array}$ \\
\hline 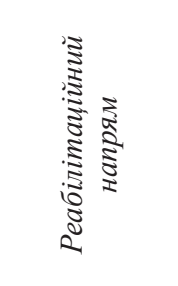 & $\begin{array}{l}\text { Передбачає вивчення } \\
\text { процесів комплексного, } \\
\text { поетапного, відновлюваль- } \\
\text { ного лікування патологіч- } \\
\text { них станів та різноманітних } \\
\text { захворювань }\end{array}$ & $\begin{array}{l}\text { Отримання нових наукових даних, } \\
\text { удосконалення методів профілактики } \\
\text { та відновлювального лікування захво- } \\
\text { рювань і травм, що сприятиме збере- } \\
\text { женню здоров’я, покращанню якості } \\
\text { життя, скороченню термінів тимча- } \\
\text { сової непрацездатності, зменшенню } \\
\text { ускладнень та інвалідизації населення }\end{array}$ \\
\hline
\end{tabular}

У плані дослідження теоретичних засад соціально-психологічної реабілітації дітей та молоді з інвалідністю засобами інклюзивного туризму міждисциплінарний підхід дозволяє синтезувати теорії інноваційних процесів із різних наукових сфер для моделювання інноваційних інклюзивних процесів і розробки інтегративних технологій соціальної інтеграції та соціалізації людей з інвалідністю.

Такі міждисциплінарні дослідження спрямовані на пошук шляхів застосування теоретичних концепцій, розв'язання практичних проблем інклюзивної освіти, іiі соціально-психологічного компонента, отримання конкретних результатів у практиці інноваційної діяльності 
закладів освіти. У міждисциплінарному ракурсі соціально-психологічні аспекти інклюзії безпосередньо пов'язані із прикладними потребами освітньої галузі й охоплюють усі підструктури інноваційної діяльності: цілі, принципи, зміст, методи, засоби й форми.

\section{3. Технологічний рівень міждисциплінарного дослідження}

Тому технологічний рівень інтеграції практико-орієнтованих знань спрямований на виявлення ефективних механізмів проектування, упровадження та застосування інклюзивного туризму як засобу соціально-психологічної реабілітації, розробку його методики, оптимальних форм здійснення та моніторингу ефективності його діяльності.

Реалізацію технологічного рівня розгляду проблеми дитячої інвалідності з позицій міждисциплінарності вважаємо за доцільне здійснювати з врахуванням іiі медичного, соціального, морального та економічного значення.

Вивчення сучасного стану системи реабілітації, дозволяє відзначити розмитість дій і відсутність координації в роботі як медичних організацій, так і різних установ з питань освіти, виховання, психологічного супроводу, соціальної підтримки дітей з інвалідністю, а також iз питань допомоги сім'ям, у яких виховуються такі діти, що в цілому негативно позначається на успішності їхньої соціальної адаптації та інтеграції.

Діти з інвалідністю часто мають проблеми, пов'язані із фізичною мобільністю та спілкуванням. Низький рівень психічного розвитку, ступінь їхньої самостійності і особливості їхньої поведінки призводять до того, що батьки свідомо маніпулюють послугами фахівців. Не маючи можливості виходити з дому, діти не отримують досвіду спілкування з іншими дітьми, із дорослими, а досвід переживання страждань від дорослих при відвідуванні закладів охорони здоров'я примушує бути осторонь від чужих людей. Ці фактори вмотивовують гостру необхідність постійного патронажного супроводу цілого ряду спеціалістів, а також пошуку ефективних технологій соціально-психологічної реабілітації.

Саме інклюзивний реабілітаційно-соціальний туризм є ефективною технологією комплексної реабілітації, що передбачає створення мультидисциплінарної команди, до складу якої мають входити про- 
фесіонали з різних сфер: педагоги, психологи, соціальні педагоги і соціальні працівники, медики, реабілітологи, інструктори з туризму, краєзнавці тощо. Така практика має відбуватися у тісній співпраці із батьками дітей з інвалідністю, що найбільш реальним $\epsilon$ в умовах інклюзивного туризму (рис. 1).

У таких мультидисциплінарних командах повинна існувати ієрархічна філософія, філософія співпраці між фахівцями. Відносини між ними будуються на основі рівноправ'я. Робота команди грунтується на обміні знаннями між фахівцями з різним досвідом та прагненні

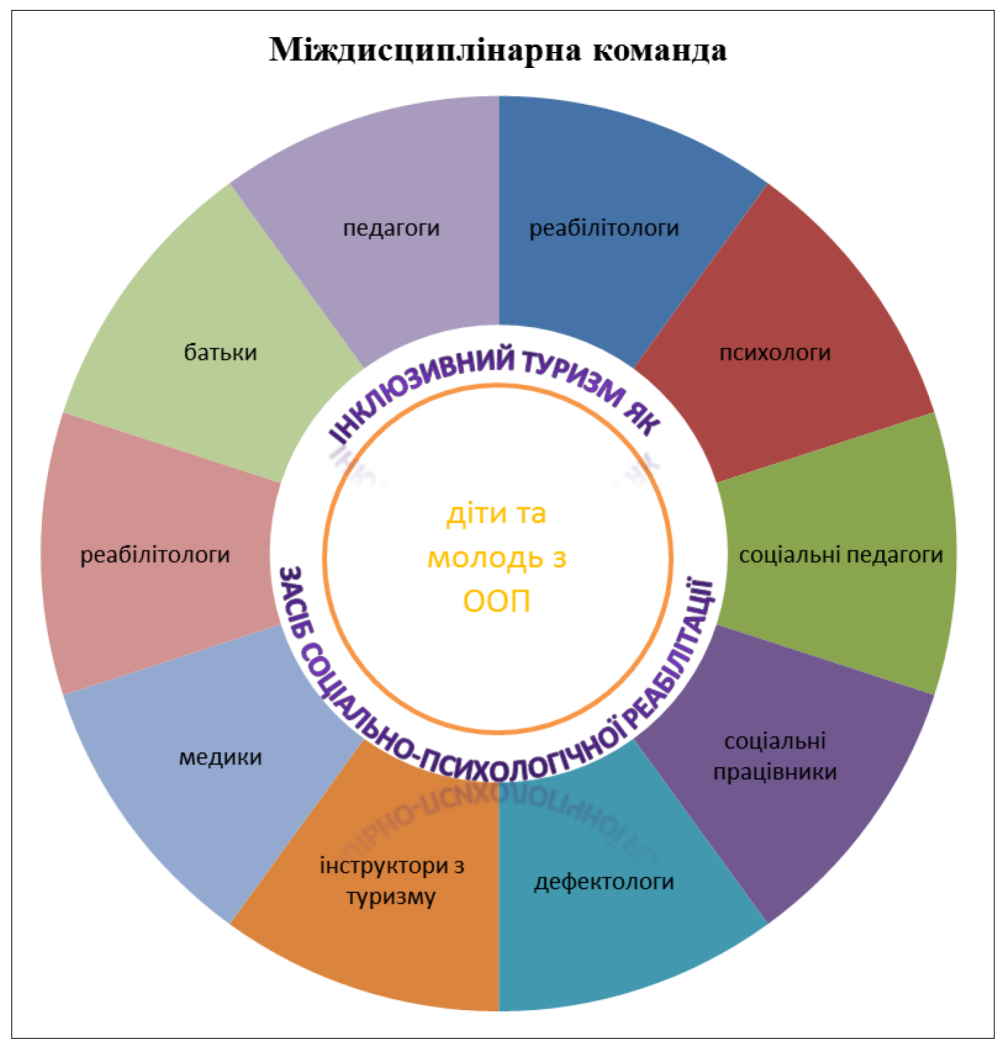

Рис. 1. Мультидисциплінарна команда комплексної реабілітації дітей та молоді з ООП засобами інклюзивного туризму 
працювати разом над досягненням спільної мети. При цьому основними характеристиками ефективної співпраці $є$ бажання і добра воля iii учасників співпрацювати, відповідати за кінцеві результати та цінувати внесок кожного учасника. Ефективна співпраця характеризується також довірою і залученням усіх учасників цього процесу до розв'язання проблем. Інші характеристики ефективної співпраці містять чітке та погоджене усіма членами команди бачення майбутнього для дитини; відданість ідеї спільної роботи адже різні перспективи і здібності збільшують ефективність команди; взаємозалежність, що передбачає визначення спільних цілей [16].

Рівень ефективності діяльності міждисциплінарної команди в умовах соціально-психологічної реабілітації визначається за допомогою комплексу методів, основними з яких є спостереження, аналіз конкретної ситуації, аналіз результатів діяльності, анкетування, тестування, метод незалежних характеристик, метод експертних оцінок, порівняльний аналіз, класифікація, систематизація, типологізація, шкалування, моделювання тощо.

Отже, міждисциплінарний підхід до практики соціально-психологічної реабілітації дітей та молоді з інвалідністю передбачає професійну співпрацю фахівців різних сфер. Кожен із них володіє відповідними професійними знаннями і набором специфічних компетенцій.

\section{4. Організаційний рівень міждисциплінарного дослідження}

Існує ще один рівень міждисциплінарного підходу до проблеми соціально-психологічної реабілітації дітей та молоді з інвалідністю засобами інклюзивного реабілітаційно-соціального туризму - організаційний. Державної політика у сфері ювенології зорієнтована на забезпечення прав дітей та молодих людей з інвалідністю на повноцінну участь у громадському житті, отримання якісної освіти всіх рівнів, кваліфікованої медичної допомоги, на охорону здоров'я та реабілітацію, соціалізацію, юридичну допомогу, соціальний захист, доступне середовище тощо. Саме в інклюзивному реабілітаційно-соціальному туризмі задіяні всі 4 сфери, серед яких - організація охорони здоров'я, соціального обслуговування, заклади освіти, недержавні організації (Ст. 4 Закону України «Про основи соціальної захищеності осіб з інвалідністю в Україні», Конвенції про права осіб з інвалідністю). 
Здійснимо характеристику кожної із сфер, що дозволить схарактеризувати не лише внесок закладів медицини, соціального захисту, освіти та громадськості у процес реабілітації людей з інвалідністю, а й сприятиме виявленню «точок дотику» у співпраці різних за профілем установ та організацій, забезпечить перспективне бачення єдиної спрямованості цих сфер та обгрунтування механізму цілісної системи комплексної реабілітації.

Державна політика $y$ сфері охорони здоров'я зорієнтована на надання якісного медичного обслуговування, у тому числі людям 3 інвалідністю. Інвалідність як міра втрати здоров'я визначається шляхом експертного обстеження в органах медико-соиіальної експертизи (МСE) центрального органу виконавчої влади.

У повноваженнях МСЕ приймати експертне рішення про групу інвалідності кожному громадянину, якого визнано інвалідом, до того ж у Центрі медико-соціальної експертизи складається індивідуальна програма реабілітації (IПР).

ІПР - це комплекс оптимальних для інваліда реабілітаційних заходів, спрямованих на відновлення, компенсацію порушених чи втрачених функцій організму. В ІПР зазначено конкретні заходи щодо реабілітації, передбачено їх послідовність, обсяги та терміни виконання. Спеціалісти МСЕ розробляють IПР на основі плану реабілітаційних заходів, який складається лікарем лікувально-профілактичного закладу, що лікує громадянина і направляє його для проходження медико-соціальної експертизи.

Індивідуальна програма реабілітації є обов'язковою для виконання державними органами, підприємствами (об'єднаннями), установами i організаціями. ІПР має рекомендаційний характер для інваліда, який, у свою чергу має право відмовитися від будь-якого виду, форми та обсягу реабілітаційних заходів, передбачених його індивідуальною програмою реабілітації.

Саме з ІПР необхідно звернутися до закладів соиіальної сфери стосовно заходів психолого-педагогічної реабілітації за місцем проживання.

Соціальний захист осіб 3 інвалідністю $є$ складовою діяльності держави щодо забезпечення прав і можливостей осіб з інвалідністю нарівні з іншими громадянами та полягає у наданні соціальних послуг у формі соціального обслуговування та соціального забезпечення. 
У цьому контексті інклюзивний реабілітаційно-соціальний туризм стає інноваційною соціальною послугою для особи з інвалідністю потужним засобом активної реабілітації, що структурно включає в себе психологічні, педагогічні, фізичні, фізкультурно-спортивні, соціально-побутові та медичні заходи.

Отже, за висновком МСЕ інклюзивний туризм може бути рекомендований до ІПР, а заклади соціальної сфери, зокрема Управління праці та соціального захисту, до свого спектру соціальних послуг можуть включати таку соціальну послугу, а також створювати відповідні структурні підрозділи чи відділи [17].

У цьому відношенні актуальним є забезпечення доступності до об'єктів фізичного оточення шляхом придбання спеціалізованого транспорту для перевезень осіб з інвалідністю, які рухаються на візках, та інших маломобільних груп населення, а також розробка та впровадження туристичних маршрутів із урахуванням особливостей психологічного стану та потреб відвідувачів.

Послугу інклюзивного туризму вмотивовано доцільно впроваджувати в умовах закладів освіти всіх рівнів. Нормативно-правові акти України декларують, що навчальні заклади надають освітні послуги особам з інвалідністю нарівні з іншими громадянами, у тому числі шляхом створення належного кадрового, матеріально-технічного забезпечення та забезпечення розумного пристосування, що враховує індивідуальні потреби особи з інвалідністю.

В останні десятиріччя активно формуються організаційні та змістові засади інклюзивного навчання - системи освітніх послуг, гарантованих державою, що базується на принципах недискримінації, урахування багатоманітності людини, ефективного залучення та включення до освітнього процесу всіх його учасників [11].

Для оптимізації процесів інклюзії у сфері освіти органи державної влади та органи місцевого самоврядування утворюють інклюзивно-ресурсні центри з метою забезпечення реалізації права на освіту та психолого-педагогічний супровід дітей з особливими освітніми потребами.

Важливим суб'єктом у наданні допомоги здобувачам освіти 3 особливими освітніми потребами є психологічна служба. 2017 рік став роком реформування психологічної служби системи освіти. На початку року наказом МОН України затверджено нову структуру дер- 
жавної наукової установи «Інститут модернізації змісту освіти», до складу якої увійшов новий структурний підрозділ - відділ психологічного супроводу та соціально-педагогічної роботи. Відповідно до чинних нормативних документів у сфері освіти, психологічне забезпечення освітнього процесу в закладах освіти здійснюють практичні психологи, а соціально-педагогічний патронаж - соціальні педагоги.

3 огляду на інноваційність та комплексність інклюзивний туризм оптимально включити до спектру психолого-педагогічних послуг як комплексної системи заходів з організації освітнього процесу та розвитку особи з особливими освітніми потребами, що передбачені індивідуальною програмою розвитку та надаються педагогічними працівниками закладів освіти, реабілітаційних установ системи охорони здоров'я, соціального захисту, фахівцями інклюзивно-ресурсного центру.

Діяльність держави щодо осіб з інвалідністю виявляється у створенні правових, економічних, політичних, соціальних, психологічних та інших умов для забезпечення їхніх прав і можливостей нарівні 3 іншими громадянами для участі в суспільному житті.

Відповідно до ЗУ «Про основи соціальної захищеності осіб 3 інвалідністю», громадські організаиії осіб з інвалідністю, їх спілки створюються з метою забезпечення рівних прав і можливостей осіб 3 інвалідністю та їх соціального захисту, виявлення, усунення перепон і бар'єрів, що перешкоджають забезпеченню прав і задоволенню потреб таких осіб, у тому числі стосовно доступу їх нарівні з іншими громадянами до об'єктів фізичного оточення, транспорту, інформації та зв'язку, а також з урахуванням індивідуальних можливостей, здібностей та інтересів - до освіти, праці, культури, фізичної культури i спорту, надання соціальних послуг, залучення осіб з інвалідністю до суспільної діяльності, здійснення громадського контролю за дотриманням прав осіб з інвалідністю, представництва їхніх інтересів та усунення будь-яких проявів дискримінації стосовно осіб з інвалідністю, що мають право користуватися пільгами і преференціями, передбаченими законодавством [12].

Особливість сучасних підходів у сфері соціального захисту полягає в об'єднанні зусиль громадськості, органів державної влади та державних наукових, освітніх установ щодо створення умов для задоволення та захисту конституційних прав людей з інвалідністю, їхніх законних, 
соціальних, економічних, творчих, національно-культурних та інших спільних інтересів; у пошукові, розробці та впровадженні інноваційних практик соціально-психологічної реабілітації людей з інвалідністю, що $\epsilon$ важливою передумовою соціальної інтеграції як повноцінних і повноправних учасників життєдіяльності. Саме співпраця між громадськими організаціями та державою має значний потенціал для розвитку соціально-гуманітарної сфери, підвищення якості соціальних послуг.

Упровадження соціальної послуги для дітей та молоді з інвалідністю засобами інклюзивного туризму - взірець такої співпраці і реалізації сучасних вимог реформування системи соціального захисту в країні водночас.

Громадські організації не лише здійснюють безпосереднє адресне надання соціальних послуг на рівні місцевої громади, а й займаються вивченням потреб і очікувань своїх членів, збором і акумулюванням інформації про попит на такі послуги та зміни соціальної ситуації у місцевих громадах. У ході впровадження соціальної послуги інклюзивного туризму вони у своїй діяльності зорієнтовані на та профілактику негативних явищ, пов'язаних з інвалідністю та їх подолання, на допомогу сім'ям, які виховують дитину з інвалідністю, а також на захист соціально-психологічного здоров'я таких людей тощо. Громадські організації беруть участь у формуванні місцевих соціальних програм та плануванні розвитку системи соціальних послуг на місцевому рівні, здійснюють громадський контроль за якістю надання такої соціальної послуги та ефективністю місцевих соціальних програм.

У цілому для посилення участі громадських організацій у наданні соціальних послуг потрібно здійснювати пошук інноваційних форм роботи, працювати на випередження, здійснювати моніторинг потреб людей з інвалідністю, упроваджувати ефективні механізми соціальної підтримки у єдності державної влади, недержавного сектору, орієнтуватися на виявлення потенційних можливостей людей з інвалідністю задля успішної соціальної інтеграції та соціалізації.

Власне, така організаційна єдність і співпраця установ профільних міністерств (рис. 2), а саме: Центрів медико-соціальної експертизи Міністерства охорони здоров'я України; Управління праці та соціального захисту населення Міністерства соціальної політики України; закладів освіти всіх рівнів, інклюзивно-ресурсних центрів, пси- 


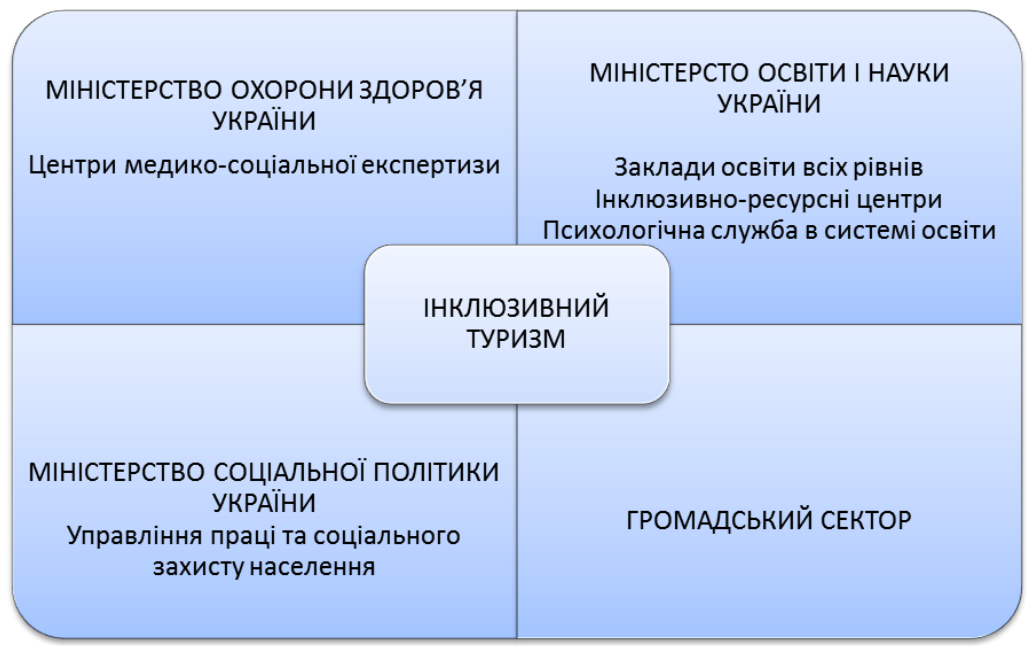

\section{Рис. 2. Організаційна сдність і співпраця установ профільних міністерств}

хологічної служби Міністерства освіти і науки України; громадських організацій інвалідів та їхніх спілок - щодо соціально-психологічної реабілітації дітей та молоді з інвалідністю сприяє підвищенню якості реабілітаційної допомоги шляхом надання людині з обмеженими можливостями ефективної, своєчасної, достатньої соціальної послуги інклюзивного туризму, що спрямована на конкретну особу, на її повноцінну інтеграцію в суспільну діяльність.

\section{4. Висновки}

Таким чином, міждисциплінарний підхід спроможний забезпечити комплексне обгрунтування і розробку функціонування системи соціально-психологічної реабілітації дітей та молоді з інвалідністю засобами інклюзивного туризму на методологічному, технологічно-практичному й організаційному рівнях.

Мета методологічного рівня полягає в інтеграції закономірностей і принципів, взаємодоповненні різних концепцій і методів наукового пізнання сутності та джерел зародження, становлення й утвердження інклюзії в освіті, упровадження інноваційних практик і технологій 
соціально-психологічної реабілітації. У процесі міждисциплінарного синтезу потребують розв'язання питання дифузії в освітню інклюзію понять, концепцій, моделей, принципів, методів, онтологічних уявлень 3 інших наукових галузей (інклюзія, туризм, соціальна робота, педагогіка, соціальна педагогіка, психологія, краєзнавство, реабілітаційна географія, медична реабілітація тощо), доцільності й правомірності їх застосування для розробки інноваційних теорій і технологій соціально-психологічної реабілітації.

Технологічний рівень інтеграції є практичним втіленням концепцій, теорій, систем у форматі міждисциплінарної команди, до складу якої входять педагоги, психологи, соціальні педагоги і соціальні працівники, медики, реабілітологи, інструктори $з$ туризму, краєзнавці, а також батьки.

Організаційний рівень передбачає вироблення єдиної мети роботи для різнопрофільних установ та закладів (Центри медико-соціальної експертизи Міністерства охорони здоров'я України; Управління праці та соціального захисту населення Міністерства соціальної політики України; заклади освіти всіх рівнів, інклюзивно-ресурсні центри, психологічна служба Міністерства освіти і науки України; громадські організації інвалідів та їхні спілки) стосовно надання комплексної реабілітаційної допомоги для людей з інвалідністю.

Таким чином, загальнотеоретичне осмислення ключових питань соціально-психологічної реабілітації дітей та молоді з інвалідністю засобами інклюзивного туризму можливе лише в межах міждисциплінарного підходу, який забезпечує фундаментальний аналіз, інтерпретацію та інтеграцію знань, використання різних методів пізнання, $\mathrm{i}$ забезпечуючи тим самим перехід до нового етапу іiі розвитку, адекватному сучасній динаміці соціальних відносин.

\section{Список літератури:}

1. Гордійчук О.Є. Міждисциплінарний підхід як невід'ємна умова інклюзивної діяльності. Наука та освіта - новий вимір. Педагогіка та психологія. T. III(31), № 61, 2015. C. 25-28.

2. Мирский Э.М. Междисциплинарные исследования и дисциплинарная организация науки. Москва : Наука, 1980. 304 с.

3. Снопкова Е.И. Актуальность междисциплинарного подхода в педагогических исследованиях: научное обоснование. Интегращия образования. T. 19. № 1(78). 2015. C. 111-117. 
4. Коновальчук I.I. Міждисииплінарний підхід у дослідженні проблем педагогічної інноватики. Interdyscyplinarnosc pedagogiki i jej subdyscypliny / Pod redakcja Zofii Szaroy, Franciczka Szloska / V польсько-украӥнський форум. 2013. C. 261-269.

5. Колупаєва А.А., Таранченко О.М. Інклюзивна освіта: від основ до практики : монографія. Київ : ТОВ «АТОПОЛ», 2016. 152 с.

6. Безкоровайна Л.В. Теоретичні і методичні засади професійної підготовки майбутніх фахівців з туризмознавства у вищих навчальних закладах : автореф. дис. на здобуття наук. ступеня д-ра. пед. наук: 13.00.04. Запоріжжя, 2018. 43 c.

7. Про соціальні послуги : Закон України від 19.04.2003 р. № 966-IV. Дата оновлення: 07.01.2018. URL: https://zakon.rada.gov.ua/laws/show/966-15 (дата звернення: 17.10.2019).

8. Енциклопедія для фахівців соціальної сфери / за заг. ред. І. Д. Звєрєвої. М-во освіти і науки, молоді та спорту України, Ін-т проблем виховання НАПН України та ін. Київ. Сімферополь : Універсум, 2012. 535 с.

9. Панок В.Г. Прикладна психологія. Теоретичні проблеми : монографія. Київ : Ніка-Центр, 2017. 188 с.

10. Енциклопедія освіти. Акад. пед. наук України / гол. ред. В. Г. Кремень. Київ : Юрінком Інтер, 2008. 1040 с.

11. Оришко С.П. Виховні можливості туристсько-краєзнавчої діяльності. Науковий вісник Ужгородського національного університету Серія «Педагогіка, соиіальна робота». 2011. Вип. 20. С. 96-99.

12. Бєлоусова Н. Теоретичні аспекти походження та використання поняття «реабілітаційна географія». Науковий вісник Херсонського державного університету. Серія «Географічні науки». 2018. Вип. 8. С. 229-233.

13. Сапункова С.С., Піц Л.О., Гутніцька А.Ф. та ін. Медична та соціальна реабілітація : навч.-метод. посіб. Київ : ВСВ «Медицина», 2018. 280 с.

14. Софій Н.3. Основні види і моделі надання додаткової підтримки дітям з особливими освітніми потребами в умовах загальноосвітнього навчального закладу. Інновачійна діяльність педагога в умовах реформування шкільної освіти. Якість шкільної освіти та інструментарії ї̈ оцінювання : матеріали Всеукр. наук.-практ. інтернет-конф. 20-25 квіт. 2015. С. 1-8.

15. Управління праці та соціального захисту Уманської міської ради. Соціальні послуги. URL: https://umanupszn.gov.ua/socialni-poslugi/ (дата звернення: 17.10.2019).

16. Про освіту : Закон України від 5.09.2017 р. № 2145-VIII. Дата оновлення 09.08.2019. URL: https://zakon.rada.gov.ua/laws/show/2145-19 (дата звернення: 17.10.2019).

17. Про основи соціальної захищеності осіб 3 інвалідністю : Закон України від 21.03.1991 р. № 875-XII. Дата оновлення 09.08.2019. URL: https://zakon.rada.gov.ua/laws/show/875-12 (дата звернення: 17.10.2019). 


\section{References:}

1. Hordiichuk, O. Ye. (2015). Mizhdystsyplinarnyi pidkhid yak nevid'iemna umova inkliuzyvnoi diialnosti [An interdisciplinary approach as an integral part of inclusive activity]. Nauka ta osvita - novyi vymir. Pedahohika ta psykholohiia, vol. III(31), issue 61, pp. 25-28.

2. Mirskij, Je. M. (1980). Mezhdisciplinarnye issledovanija i disciplinarnaja organizacija nauki [Interdisciplinary research and the disciplinary organization of science]. Moskva: Nauka. (in Russian)

3. Snopkova, E.I. (2015). Aktual'nost' mezhdisciplinarnogo podhoda v pedagogicheskih issledovanijah: nauchnoe obosnovanie [The relevance of an interdisciplinary approach in pedagogical research: a scientific justification]. Integracija obrazovanija. T. 19. № 1(78).

4. Konovalchuk, I. I. (2013). Mizhdystsyplinarnyi pidkhid u doslidzhenni problem pedahohichnoi innovatyky [An interdisciplinary approach in the study of pedagogical innovation problems]. Interdyscyplinarnosc pedagogiki i jej subdyscypliny / Pod redakcja Zofii Szaroy, Franciczka Szloska / V polsko-ukrainskyi forum.

5. Kolupaieva, A. A., Taranchenko, O. M. (2016). Inkliuzyvna osvita: vid osnov do praktyky: monohrafiia [Inclusive education: from the basics to practice]. Kyiv: TOV «ATOPOL».

6. Bezkorovaina, L. V. (2018). Teoretychni i metodychni zasady profesiinoi pidhotovky maibutnikh fakhivtsiv z turyzmoznavstva u vyshchykh navchalnykh zakladakh [Theoretical and methodological foundations of professional training of future specialists in tourism in higher education]: avtoref. dys. na zdobuttia nauk. stupenia d-ra. ped. nauk: 13.00.04. Zaporizhzhia.

7. Pro sotsialni posluhy [About social services]: Zakon Ukrainy vid 19.04.2003 r. № 966-IV. Data onovlennia: 07.01.2018. URL: https://zakon.rada.gov.ua/laws/ show/966-15

8. Entsyklopediia dlia fakhivtsiv sotsialnoi sfery [Encyclopedia for social professionals] (2012) / za zah. red. I. D. Zvierievoi. M-vo osvity i nauky, molodi ta sportu Ukrainy, In-t problem vykhovannia NAPN Ukrainy ta in. Kyiv. Simferopol: Universum.

9. Panok, V. H. (2017). Prykladna psykholohiia. Teoretychni problemy: monohrafiia [Applied Psychology. Theoretical problems]; Kyiv: Nika-Tsentr.

10. Entsyklopediia osvity [Encyclopedia of Education. Akad. ped. nauk Ukrainy / hol. red. V. H. Kremen (2008). Kyiv: Yurinkom Inter.

11. Oryshko, S. P. (2011). Vykhovni mozhlyvosti turystsko-kraieznavchoi diialnosti [Educational opportunities of tourism and local lore]. Naukovyi visnyk Uzhhorodskoho natsionalnoho universytetu. Seriia «Pedahohika, sotsialna robota», no. 20, 96-99.

12. Bielousova, N. (2018). Teoretychni aspekty pokhodzhennia ta vykorystannia poniattia «reabilitatsiina heohrafiia» [Theoretical aspects of the origin and use of the concept of «rehabilitation geography»]. Naukovyi visnyk Khersonskoho derzhavnoho universytetu. Seriia «Heohrafichni nauky», no. 8, pp. 229-233. (in Ukrainian)

13. Sapunkova, S. S., Pits, L. O., Hutnitska, A .F. ta in. (2018). Medychna ta sotsialna reabilitatsiia [Medical and social rehabilitation]. navch.-metod. posib. Kyiv: VSV «Medytsyna». (in Ukrainian) 
14. Sofii, N. Z. (2015). Osnovni vydy i modeli nadannia dodatkovoi pidtrymky ditiam $\mathrm{z}$ osoblyvymy osvitnimy potrebamy $\mathrm{v}$ umovakh zahalnoosvitnoho navchalnoho zakladu [Basic types and models of providing additional support for children with special educational needs in the context of a comprehensive educational institution]. Innovatsiina diialnist pedahoha $\mathrm{v}$ umovakh reformuvannia shkilnoi osvity. Yakist shkilnoi osvity ta instrumentarii yii otsiniuvannia. materialy Vseukr. nauk.prakt. internet-konf. 20-25 kvit. (in Ukrainian)

15. Upravlinnia pratsi ta sotsialnoho zakhystu Umanskoi miskoi rady. Sotsialni posluhy. URL: https://umanupszn.gov.ua/socialni-poslugi/

16. Pro osvitu [About education]. Zakon Ukrainy vid 5.09.2017 r. № 2145-VIII. Data onovlennia 09.08.2019. URL: https://zakon.rada.gov.ua/laws/show/2145-19

17. Pro osnovy sotsialnoi zakhyshchenosti osib z invalidnistiu [On the basics of social protection for persons with disabilities]: Zakon Ukrainy vid 21.03.1991 r. № 875-XII. Data onovlennia 09.08.2019. URL: https://zakon.rada.gov.ua/laws/ show/875-12 